\title{
Pulmonary thromboembolism in childhood: A single-center experience from Turkey
}

\author{
Betul Tavil, Barıs Kuskonmaz, Nural Kiper, Mualla Cetin, Fatma Gumruk, and Aytemiz Gurgey, MD
}

OBJECTIVE: This study was designed to evaluate the clinical characteristics, acquired and congenital risk factors, treatment strategies, and long-term outcome in pediatric pulmonary thromboembolism (PTE) cases followed in our center in Turkey.

SUBJECTS: Of the total 470 pediatric patients with thrombosis referred to our center, 16 (3.4\%) had PTE. The mean age of the children with PTE was $10.3 \pm 6.8$ years (range: $1.5-20.0$, median: 10.5 ), and $12(75.0 \%)$ were boys.

RESULTS: The mean follow-up period was $28.9 \pm 21.0$ months (range: $3-66$, median: 22 ). During the follow-up period, recurrence was observed in three children (18.8\%). The mean time from the appearance of symptoms to accurate diagnosis was $6.4 \pm 4.0$ days (range: $2-10)$. Six patients $(37.5 \%)$ were initially diagnosed as having pneumonia. After they were hospitalized and showed no clinical improvement with broad-spectrum antibiotic treatment, the accurate diagnosis of PTE was established. Of these 16 patients with PTE, $8(50 \%)$ had associated thrombosis and $6(37.5 \%)$ had congenital heart diseases. Infections including septic arthritis and osteomyelitis $(n=1)$, cytomegalovirus infection $(n=1)$, and infective endocarditis $(n=2)$ were detected in our patient group. In addition, two patients had a central venous line and one patient had obesity associated with malignancy. Other underlying diseases included thalassemia major, Behçet disease, antiphospholipid antibody syndrome, and autoimmune lymphoproliferative disorder in one patient each. Factor V Gl69lA heterozygous mutation was detected in two children, and methylene tetrahydrofolate reductase C677T homozygous mutation was detected in one child. A high level of factor VIII was the most common $(8 / 16,50 \%)$ laboratory risk factor in our patient group, and 12 children $(75.0 \%)$ had a high D-dimer level. Among 16 children with PTE, one child had one, three children had two, five children had three, three children had four, and four children had five laboratory and/or clinical risk factors. Therefore, all children with PTE had at least one laboratory and/or clinical risk factor that facilitated development of thrombosis. In addition, according to the risk assessment for persistence or recurrence of venous thrombosis in children conducted by Manco-Johnson, 12 children $(75 \%)$ with PTE in the present study had high-risk criteria.

CONCLUSION: When a child with thrombosis at any site of the body develops unexpected respiratory symptoms or pneumonia unresponsive to antibiotic treatment, imaging studies should be performed for diagnosis of PTE. Furthermore, thrombotic children with high-risk criteria should be followed closely for the development of PTE. (Heart Lung® 2009;38:56-65.)

$\mathrm{P}$ ulmonary thromboembolism (PTE) results from obstruction of the pulmonary artery by endogenous or exogenous embolus or local thrombus. It is an uncommon but life-threatening disorder in children. Because the clinical findings

\footnotetext{
From the Hacettepe University Faculty of Medicine, Ihsan Dogramacı Children's Hospital, Sihhiye-Ankara, Turkey.

Corresponding author: Aytemiz Gurgey, MD, Hacettepe University Faculty of Medicine, Ihsan Dogramacl Children's Hospital, Pediatric Hematology Unit, 06100-Sihhiye-Ankara/Turkey.

0147-9563/\$ - see front matter

Copyright (c) 2009 by Mosby, Inc

doi:10.1016/j.hrtlng.2007.06.004
}

are nonspecific, suspicion is required for early and accurate diagnosis of pediatric PTE. In childhood, PTE is often overlooked because the clinical presentation may be altered or masked by other concomitant diseases. The incidence of PTE is much less in children than in adults. In recent years, mostly case reports and case series have been reported in the literature ${ }^{1-7}$ However, large studies in children with PTE have been conducted on autopsy examination. An incidence of PTE ranging from .73\% to $4.3 \%$ has been reported in pediatric autopsy studies. ${ }^{8,9}$ With improvement in imaging techniques and increased disease recognition, the incidence of pediatric PTE 
has gradually increased. In Canadian and Dutch pediatric registries, incidence rates of PTE were found to be .86 per 10,000 pediatric hospital admissions and .14 per 100,000 children (range: 0-18 years) annually. 2,10

Nevertheless, there are a limited number of publications about pediatric PTE, and some of them are review articles that explain the incidence of PTE. ${ }^{1-7}$ However, clinical characteristics, risk factors, treatment, and outcome in pediatric PTE are not sufficiently understood. Therefore, we aimed to evaluate clinical characteristics, acquired and congenital risk factors, treatment strategies, and long-term outcome in pediatric PTE cases followed in our center.

\section{MATERIALS AND METHODS}

Between January of 1998 and August of 2006, 470 pediatric patients were admitted to Hacettepe University Faculty of Medicine, Pediatric Hematology Unit, for evaluation of thrombosis. Of these 470 children with thrombosis, those with respiratory symptoms and young children with pneumonia who do not improve with antibiotic treatment were evaluated with imaging studies for PTE; as a result of this evaluation, 16 children (3.4\%) were diagnosed with PTE

These 16 patients' outpatient and inpatient charts were reviewed for additional thrombosis, underlying diseases, prothrombotic risk factors, type and duration of anticoagulation therapy, resolution of thrombosis, and outcome. The diagnosis of PTE was made using ventilation-perfusion scintigraphy, helical computed tomography, magnetic resonance imaging, and pulmonary angiography. In addition, the diagnosis of associated thrombosis was made using Doppler ultrasonography, computed tomography, and magnetic resonance imaging techniques.

Thrombotic workup, including protein $\mathrm{C}$, protein $\mathrm{S}$, antithrombin III, lipid profiles (triglycerides, cholesterol, very low-density lipoprotein, low-density lipoprotein, high-density lipoprotein), lipoprotein A level, homocysteine level, anticardiolipin and antiphospholipid antibodies (APAs), factor II, V, VII, VIII, IX, and XI levels, factor V G1691A (FV Leiden), prothrombin G20210A, and methylene tetrahydrofolate reductase (MTHFR) mutations, was performed in all patients with PTE. Fibrinogen (normal values, $144-430 \mathrm{mg} / \mathrm{dL}$ ), factor II (normal values, $70 \%-120 \%$ ), factor V (normal values, 70\%-120\%), factor VII (normal values, 70\%-130\%), factor VIII (normal values, 53\%-170\%), factor IX (normal values, 60\%-170\%), and factor XI (normal values, 70\%-150\%) were studied by measurement of the clotting time (Diagnos- tica Stago, Asnieres, France). Plasma protein $\mathrm{C}$ activity (normal values, 70\%-130\%) and antithrombin III activity (normal values, 80\%-120\%) were measured with the use of calorimetric substrates (STA Stachrom, Diagnostica Stago). Free protein S antigen was measured using commercially available immunoturbidimetric assay kits (normal values, 70\%130\%) (STA Liatest, Diagnostica Stago). APAs (normal values, 0-10 RU/mL) were determined with enzyme-linked immunosorbent assay techniques (Euroimmun, Lübeck, Germany). Homocysteine (normal values, $5-15 \mu \mathrm{mol} / \mathrm{L}$ ) and lipoprotein a (normal values, $0-30 \mathrm{mg} / \mathrm{dL}$ ) were tested using the Immage immunochemistry system by the nephelometry method (Beckman, Fullerton, Calif).

High molecular weight DNA was extracted from peripheral blood by standard procedures. FV G1691A, prothrombin G20210A, and MTHFR C677T mutations were detected using the methods described earlier. ${ }^{1-13}$ SPSS for Windows version 10.0 (SPSS Inc, Chicago, Ill) was used for evaluation of the data. Type of thrombosis, underlying diseases, prothrombotic risk factors, type and duration of anticoagulation therapy, and outcome in children with PTE are shown in Table I.

\section{RESULTS}

The mean age of the 16 children with PTE (12 boys, $75 \%$ ) was $10.28 \pm 6.83$ years (range: $1.5-20.0$, median: 10.5 years). Although three patients (case numbers 2, 5, and 12) were aged more than 18 years $(20,20$, and 19 years), they continued to be followed at the children's hospital by their primary physicians because of their chronic and congenital diseases. The mean follow-up period was $28.88 \pm 21.00$ months (range: 3-66 months, median: 22 months). During the follow-up period, recurrence was observed in $3(18.8 \%)$ of the 16 children. All of the clinical and laboratory data of the patients with PTE are presented in Table I. Data of completely or partially recovered patients are presented in $\mathrm{Ta}$ ble II.

\section{Clinical features}

All patients had respiratory symptoms, including tachypnea, cough, and respiratory distress, at the time of diagnosis. The mean time from the appearance of the symptoms to accurate diagnosis was 6.4 \pm 4.0 days (range: $2-10$ days). Six patients (37.5\%) were initially diagnosed as having pneumonia. After they were hospitalized and no clinical improvement was observed after broad-spectrum antibiotic treat- 


\section{Table I}

Site of thrombosis and risk factors in patients with pulmonary thromboembolism

\begin{tabular}{|c|c|c|c|c|c|c|}
\hline $\begin{array}{l}\text { Case } \\
\text { No. }\end{array}$ & $\begin{array}{c}\text { Age } \\
(y) / \\
\text { gender }\end{array}$ & $\begin{array}{c}\text { Type of } \\
\text { thrombosis }\end{array}$ & Underlying diseases & Prothrombotic risk factors & $\begin{array}{c}\text { Type and duration of } \\
\text { anticoagulation therapy }\end{array}$ & Outcome \\
\hline 1 & $13 / \mathrm{M}$ & $\begin{array}{l}\text { PTE and DVT } \\
\text { at right } \\
\text { femoral } \\
\text { vein }\end{array}$ & $\begin{array}{l}\text { Operated craniopharyngioma } \\
\text { and obesity }\end{array}$ & $\begin{array}{l}\text { Hyperlipidemia, lupus } \\
\text { anticoagulant positivity, } \\
\text { and MTHFR homozygous } \\
\text { mutation }\end{array}$ & $\begin{array}{l}\text { Unfractionated heparin } \\
\text { for } 10 \mathrm{~d} \text { and LMWH for } \\
6 \mathrm{mo}\end{array}$ & $\begin{array}{l}\text { Alive with partial } \\
\text { recovery }\end{array}$ \\
\hline 2 & $20 / \mathrm{F}$ & PTE & $\begin{array}{l}\text { Operated congenital heart } \\
\text { disease (truncus } \\
\text { arteriosus) and infective } \\
\text { endocarditis (blood } \\
\text { culture: Acinetobacter } \\
\text { baumannii) }\end{array}$ & - & $\begin{array}{l}\text { TPA (once), } \\
\text { unfractionated heparin } \\
\text { for } 10 \mathrm{~d} \text {, and oral } \\
\text { anticoagulant for } 6 \text { mo }\end{array}$ & $\begin{array}{l}\text { Exitus with } \\
\text { complicated } \\
\text { congenital } \\
\text { heart disease } \\
\text { and infective } \\
\text { endocarditis; } \\
\text { complete } \\
\text { recovery }\end{array}$ \\
\hline 3 & $2.5 / \mathrm{M}$ & $\begin{array}{l}\text { PTE and DVT } \\
\text { at right } \\
\text { femoral } \\
\text { vein }\end{array}$ & Pneumonia & $\begin{array}{l}\text { Hyperlipidemia and elevated } \\
\text { level of factor XI }\end{array}$ & $\begin{array}{l}\text { Unfractionated heparin } \\
\text { for } 14 \mathrm{~d} \text { and LMWH for } \\
6 \mathrm{mo}\end{array}$ & $\begin{array}{l}\text { Alive with } \\
\text { complete } \\
\text { recovery }\end{array}$ \\
\hline 4 & $4.5 / \mathrm{M}$ & $\begin{array}{l}\text { PTE and DVT } \\
\text { at right } \\
\text { vena cava } \\
\text { superior }\end{array}$ & $\begin{array}{l}\text { Vitamin D-resistant rickets, } \\
\text { pneumonia, and presence } \\
\text { of catheter }\end{array}$ & $\begin{array}{l}\text { Elevated levels of } \\
\text { lipoprotein a, fibrinogen, } \\
\text { factor VIII and XI }\end{array}$ & $\begin{array}{l}\text { Thrombectomy for DVT; } \\
\text { Unfractionated heparin } \\
\text { for } 10 \mathrm{~d} \text { and LMWH for } \\
6 \text { mo for PTE }\end{array}$ & $\begin{array}{l}\text { Alive with } \\
\text { complete } \\
\text { recovery }\end{array}$ \\
\hline 5 & $20 / M$ & $\begin{array}{l}\text { PTE and DVT } \\
\text { at right } \\
\text { axillary, } \\
\text { vena cava } \\
\text { inferior, } \\
\text { and } \\
\text { subclavian } \\
\text { veins }\end{array}$ & $\begin{array}{l}\text { Thalassemia major, } \\
\text { splenectomy, and heart } \\
\text { failure }\end{array}$ & $\begin{array}{l}\text { Protein C deficiency, } \\
\text { elevated levels of } \\
\text { fibrinogen and factor VIII }\end{array}$ & $\begin{array}{l}\text { TPA (twice), } \\
\text { unfractionated heparin } \\
\text { for } 12 \mathrm{~d} \text {, and long-term } \\
\text { LMWH therapy }\end{array}$ & $\begin{array}{l}\text { Recurrence of } \\
\text { DVT, alive } \\
\text { with complete } \\
\text { recovery }\end{array}$ \\
\hline 6 & $2 / \mathrm{M}$ & PTE & Pneumonia, CMV infection & $\begin{array}{l}\text { Protein C deficiency, } \\
\text { elevated level of factor } \\
\text { VIII }\end{array}$ & $\begin{array}{l}\text { TPA (once), LMWH for } \\
10 \mathrm{~d} \text {, and oral } \\
\text { anticoagulant for } 6 \mathrm{mo}\end{array}$ & $\begin{array}{l}\text { Alive with } \\
\text { complete } \\
\text { recovery }\end{array}$ \\
\hline
\end{tabular}




\section{Table I}

Continued

\begin{tabular}{|c|c|c|c|c|c|c|}
\hline $\begin{array}{l}\text { Case } \\
\text { No. }\end{array}$ & $\begin{array}{l}\text { Age } \\
(\mathrm{y}) / \\
\text { gender }\end{array}$ & $\begin{array}{l}\text { Type of } \\
\text { thrombosis }\end{array}$ & Underlying diseases & Prothrombotic risk factors & $\begin{array}{l}\text { Type and duration of } \\
\text { anticoagulation therapy }\end{array}$ & Outcome \\
\hline 7 & $1.5 / \mathrm{M}$ & $\begin{array}{l}\text { PTE, cerebral } \\
\text { infarct, } \\
\text { renal vein } \\
\text { thrombosis, } \\
\text { and DVT } \\
\text { at right } \\
\text { subclavian } \\
\text { and } \\
\text { internal } \\
\text { jugular } \\
\text { veins }\end{array}$ & $\begin{array}{l}\text { Down syndrome, congenital } \\
\text { heart disease } \\
\text { (atrioventricular septal } \\
\text { defect), pneumonia, } \\
\text { pulmonary binding } \\
\text { operation, and presence of } \\
\text { catheter }\end{array}$ & Protein C deficiency & $\begin{array}{l}\text { TPA (twice), and long } \\
\text { term LMWH treatment } \\
\text { for recurrent } \\
\text { thrombosis }\end{array}$ & $\begin{array}{l}\text { Exitus with } \\
\text { recurrent } \\
\text { thrombosis; } \\
\text { partial } \\
\text { recovery }\end{array}$ \\
\hline 8 & $15 / M$ & $\begin{array}{l}\text { PTE and } \\
\text { thrombosis } \\
\text { in the } \\
\text { right } \\
\text { ventricle }\end{array}$ & $\begin{array}{l}\text { Congenital heart disease } \\
\text { (corrected transposition of } \\
\text { great arteries, ventricular } \\
\text { septal defect, pulmonary } \\
\text { stenosis), Blalock-Taussig } \\
\text { shunt operation }\end{array}$ & Protein S deficiency & $\begin{array}{l}\text { Unfractionated heparin } \\
\text { for } 10 \mathrm{~d} \text { and LMWH for } \\
6 \text { mo for PTE }\end{array}$ & $\begin{array}{l}\text { Alive with } \\
\text { complete } \\
\text { recovery }\end{array}$ \\
\hline 9 & $17 / \mathrm{M}$ & PTE & $\begin{array}{l}\text { Behçet disease (lung } \\
\text { involvement), aneurysm } \\
\text { in pulmonary artery }\end{array}$ & $\begin{array}{l}\text { Elevated level of } \\
\text { homocysteine }\end{array}$ & $\begin{array}{l}\text { LMWH for } 6 \text { mo, high- } \\
\text { dose } \\
\text { methylprednisolone } \\
\text { (500 mg), and } \\
\text { cyclophosphamide }\end{array}$ & $\begin{array}{l}\text { Alive with partial } \\
\text { recovery and } \\
\text { pulmonary } \\
\text { hypertension }\end{array}$ \\
\hline 10 & $9 / \mathrm{F}$ & PTE & $\begin{array}{l}\text { Infective endocarditis, } \\
\text { operated congenital heart } \\
\text { disease (atrial septal } \\
\text { defect, mitral and tricuspid } \\
\text { insufficiency), and } \\
\text { pneumonia }\end{array}$ & - & LMWH for $6 \mathrm{mo}$ & $\begin{array}{l}\text { Alive with } \\
\text { complete } \\
\text { recovery }\end{array}$ \\
\hline 11 & $12 / \mathrm{M}$ & $\begin{array}{l}\text { PTE and DVT } \\
\text { at right } \\
\text { femoral } \\
\text { vein and } \\
\text { vena cava } \\
\text { inferior }\end{array}$ & $\begin{array}{l}\text { Septic arthritis and } \\
\text { osteomyelitis at right } \\
\text { femur, pneumonia }\end{array}$ & $\begin{array}{l}\text { FV G1691A heterozygous } \\
\text { mutation, hereditary } \\
\text { protein C deficiency, } \\
\text { hyperlipidemia, and } \\
\text { elevated level of factor } \\
\text { VIII }\end{array}$ & $\begin{array}{l}\text { TPA (twice), } \\
\text { unfractionated heparin } \\
\text { for } 10 \mathrm{~d} \text {, LMWH for } 6 \\
\text { mo, and long-term oral } \\
\text { anticoagulant treatment }\end{array}$ & $\begin{array}{l}\text { Recurrence of } \\
\text { DVT, alive } \\
\text { with complete } \\
\text { recovery }\end{array}$ \\
\hline
\end{tabular}




\section{Table I}

Continued

\begin{tabular}{|c|c|c|c|c|c|c|}
\hline $\begin{array}{l}\text { Case } \\
\text { No. }\end{array}$ & $\begin{array}{c}\text { Age } \\
(y) / \\
\text { gender }\end{array}$ & $\begin{array}{l}\text { Type of } \\
\text { thrombosis }\end{array}$ & Underlying diseases & Prothrombotic risk factors & $\begin{array}{l}\text { Type and duration of } \\
\text { anticoagulation therapy }\end{array}$ & Outcome \\
\hline 12 & $19 / \mathrm{F}$ & PTE & $\begin{array}{l}\text { Congenital heart disease } \\
\text { (truncus arteriosus, } \\
\text { ventricular septal defect, } \\
\text { pulmonary atresia) and } \\
\text { Fontan operation }\end{array}$ & Elevated level of factor VIII & $\begin{array}{l}\text { Unfractionated heparin } \\
\text { for } 10 \mathrm{~d} \text {, LMWH for } \\
10 \mathrm{~d} \text {, and oral } \\
\text { anticoagulant treatment } \\
\text { for } 6 \text { mo }\end{array}$ & $\begin{array}{l}\text { Alive with partial } \\
\text { recovery and } \\
\text { pulmonary } \\
\text { hypertension }\end{array}$ \\
\hline 13 & $1.5 / \mathrm{M}$ & PTE & $\begin{array}{l}\text { Infective endocarditis (blood } \\
\text { culture: Candida albicans), } \\
\text { aganglionic megacolon }\end{array}$ & Elevated level of factor VIII & LMWH for 6 mo & $\begin{array}{l}\text { Alive with } \\
\text { sequela and } \\
\text { partial } \\
\text { recovery }\end{array}$ \\
\hline 14 & $14 / \mathrm{M}$ & PTE & $\begin{array}{l}\text { Autoimmune } \\
\text { lymphoproliferative } \\
\text { disorder }\end{array}$ & $\begin{array}{l}\text { Elevated level of factor VIII } \\
\text { and factor XI }\end{array}$ & $\begin{array}{l}\text { Unfractionated heparin } \\
\text { for } 10 \mathrm{~d} \text { and LMWH for } \\
6 \mathrm{mo}\end{array}$ & $\begin{array}{l}\text { Alive with } \\
\text { complete } \\
\text { recovery }\end{array}$ \\
\hline 15 & $7 / \mathrm{F}$ & $\begin{array}{l}\text { PTE and DVT } \\
\text { at left } \\
\text { internal } \\
\text { carotid } \\
\text { artery and } \\
\text { cerebral } \\
\text { infarct }\end{array}$ & $\begin{array}{l}\text { Antiphospholipid antibody } \\
\text { syndrome }\end{array}$ & $\begin{array}{l}\text { FV G1691 A heterozygous } \\
\text { mutation, elevated levels } \\
\text { of factor II and VIII, } \\
\text { antiphospholipid IgM (+) } \\
\text { and anticardiolipin IgM } \\
(+)\end{array}$ & $\begin{array}{l}\text { Unfractionated heparin } \\
\text { for } 10 \mathrm{~d} \text { and acetyl- } \\
\text { salicylic acid and } \\
\text { LMWH for } 6 \text { mo }\end{array}$ & $\begin{array}{l}\text { Alive with } \\
\text { sequela } \\
\text { (hemiplegia) } \\
\text { and partial } \\
\text { recovery }\end{array}$ \\
\hline 16 & $6.5 / \mathrm{M}$ & PTE & $\begin{array}{l}\text { Congenital heart disease } \\
\text { (atrial septal defect, } \\
\text { pulmonary stenosis, } \\
\text { pulmonary valvular } \\
\text { insufficiency) }\end{array}$ & $\begin{array}{l}\text { Hereditary protein } \mathrm{C} \\
\text { deficiency }\end{array}$ & $\begin{array}{l}\text { Unfractionated heparin } \\
\text { for } 10 \mathrm{~d} \text { and LMWH for } \\
6 \mathrm{mo}\end{array}$ & $\begin{array}{l}\text { Alive with partial } \\
\text { recovery and } \\
\text { pulmonary } \\
\text { hypertension }\end{array}$ \\
\hline
\end{tabular}

PTE, Pulmonary thromboembolism; DVT, deep vein thrombosis; $L M W H$, low-molecular-weight heparin; $T P A$, tissue plasminogen activator; $C M V$, cytomegalovirus; $I g$, immunoglobulin; $F V$, factor V; MTHFR, methylene tetrahydrofolate reductase. 


\section{Table II}

Data of patients with complete and partial recovery

Complete recovery

Partial recovery

No. of patients*

No. of risk factors in each patient

Mean age (mean $\pm \mathrm{SD}$; range)

Underlying disorder

Prothrombotic risk factors

3.6

$9.9 \pm 6.5$ y $(2-20)$

Pneumonia (2)

Pneumonia and catheter (1)

Thalassemia, splenectomy, and heart failure (1)

Congenital heart disease and Blalock-Taussig

$$
\text { shunt (1) }
$$

Pneumonia, congenital heart disease, and

infective endocarditis (1)

Septic arthritis and osteomyelitis (1)

Autoimmune lymphoproliferative disorder (1)

Hyperlipidemia (2)

Protein C deficiency (3)

Protein S deficiency (1)

Lipoprotein a $\uparrow(1)$

Homocysteine $\uparrow(1)$

Fibrinogen $\uparrow(2)$

Factor VIII $\uparrow(5)$

Factor IX $\uparrow(1)$

Factor XI $\uparrow(2)$

FV G1691A heterozygous mutation (1)
6

3.1

$10.7 \pm 6.8$ y (1.5-19)

Craniopharyngioma and obesity (1)

Congenital heart disease, pneumonia, and catheter (1)

Behçet disease, aneurysm in pulmonary artery (1)

Congenital heart disease and Fontan operation (1)

Antiphospholipid antibody syndrome (1)

Infective endocarditis (1)

Hyperlipidemia (1)

Factor II $\uparrow$ (1)

Factor VIII $\uparrow$ (3)

Lupus anticoagulant positivity (1)

Antiphospholipid IgM $(+)$ and anticardiolipin $\operatorname{IgM}(+)(1)$

FV G1691A heterozygous mutation (1)

MTHFR homozygous mutation (1)

$S D$, Standard deviation; Ig, immunoglobulin; FV, factor V; MTHFR, methylene tetrahydrofolate reductase.

*Expired patients were not evaluated in this table. 
ment, the accurate diagnosis of PTE was established.

\section{Imaging studies}

Of these 16 patients with PTE, all had chest radiography studies, whereas hard copies of chest radiography were available for 10 of 16 children, which revealed nonspecific abnormalities including infiltration, consolidation, and opacities. In the diagnosis of PTE, both ventilation-perfusion scintigraphy and helical computed tomography were used in eight patients, only ventilation-perfusion scintigraphy was used in four patients, only helical computed tomography was used in three patients, and pulmonary angiography was used in one patient. Therefore, ventilation-perfusion scintigraphy was the most common diagnostic imaging technique used in this group of patients (75\%). In addition, two imaging techniques were preferred in half of the patients for the accurate diagnosis of PTE.

\section{Associated thrombosis}

Of these 16 patients with PTE, 8 (50\%) had associated thrombosis. Two patients had deep vein thrombosis (DVT) at lower extremity veins, two patients had DVT at upper-extremity veins, one patient had DVT at both upper and lower-extremity veins, two patients had cerebral infarct associated with DVT, and one patient had intracardiac thrombosis (Table I).

\section{Underlying diseases}

Six patients $(37.5 \%)$ had congenital heart diseases; one underwent the Fontan operation, one underwent the Blalock-Taussig shunt operation, and four underwent other operations, including pulmonary binding operation, correction of truncus arteriosus, and atrial septal defect. Six patients (37.5\%) had probable pneumonia. Infection other than pneumonia was also detected in our patient group: septic arthritis associated with osteomyelitis in one patient, cytomegalovirus infection in one patient, and infective endocarditis in two patients. Acinetobacter baumannii and Candida albicans were detected in the blood culture of two patients with infective endocarditis. In addition, two patients had a central venous line $(\mathrm{CVL})$ and one patient had obesity associated with malignancy. Other underlying diseases included thalassemia major, Behçet disease, APA syndrome, and autoimmune lymphoproliferative disorder in one patient each. Thus, all of our patients had clinical risk factors for thrombosis (Tables I and II).

\section{Laboratory risk factors}

FV G1691A heterozygous mutation was detected in two children, and MTHFR C677T homozygous mutation was detected in one child. Hyperlipidemia was detected in three children (18.75\%), APA positivity in one child (6.25\%), and lupus anticoagulant positivity in one child $(6.25 \%)$ at the time of diagnosis. In addition, five children (31.25\%) had protein C deficiency, and one child (6.25\%) had protein S deficiency; elevated levels of factor XI, fibrinogen, factor II, homocysteine, and lipoprotein A were detected in three children (18.75\%), two children (12.5\%), one child (6.25\%), one child $(6.25 \%)$, and one child (6.25\%), respectively. A high level of factor VIII was the most common $(8 / 16,50 \%)$ laboratory risk factor in our patient group. Furthermore, 12 (75.0\%) of 16 children with PTE had a high D-dimer level (normal range in our center: .0-.5 U/dL) at the time of diagnosis. The mean D-dimer level was 4.7 $\pm 6.6 \mathrm{U} / \mathrm{dL}$ : (range: .61-18.98, median: $2.07 \mathrm{U} / \mathrm{dL}$ ).

Thus, among 16 children with PTE, one child had one, three children had two, five children had three, three children had four, and four children had five laboratory and/or clinical risk factors. Therefore, all children with PTE had at least one laboratory and/or clinical risk factor that facilitates development of thrombosis.

According to the risk assessment for persistence or recurrence of venous thrombosis in children conducted by Manco-Johnson, ${ }^{14} 12$ of 16 children with PTE in the present study had high-risk criteria.

\section{Treatment modalities and outcome}

After the diagnosis of PTE, oxygen saturation should be monitored closely. Because children with PTE may need mechanical ventilation, unfractionated heparin was used to achieve a therapeutic partial thromboplastin time of 60 to 85 seconds as initial anticoagulation therapy in $8(50 \%)$ of 16 children. Thrombolytic therapy (tissue plasminogen activator [TPA] $.5 \mathrm{mg} / \mathrm{kg} / \mathrm{h}$ for 6 hours) was used in five children $(31.25 \%)$. In three of them, TPA treatment was applied twice, whereas it was applied only once in the other two children. Low-molecular-weight heparin (LMWH) was used in three children $(18.75 \%)$ as initial treatment.

In the follow-up treatment, LMWH was used in most of the children $(12 / 16,75 \%)$ with the exception of four adolescent patients who received oral anticoagulant treatment. The duration of the anticoagulant treatment was generally 6 months, except for three patients who were recommended to have long-term anticoagulant treatment in view of their 
recurrent thrombosis despite receiving anticoagulation therapy. Two of the patients with recurrent thrombosis had only DVT and not PTE recurrence, and they are doing well with oral anticoagulation therapy. However, the other patient had recurrent and multiple thrombosis, including PTE, cerebral infarct, renal vein thrombosis, and DVT at the right subclavian and internal jugular veins, and he did not recover completely with anticoagulant therapy: he died of multiple progressive thrombosis. Anticoagulant therapy was well tolerated; major bleeding related to anticoagulant therapy was not observed in our patients. During the follow-up, seven children had partial dissolution and nine children had complete dissolution of thrombosis. Two patients died: one as the result of infection (infective endocarditis) and one as the result of recurrent, multiple, and progressive thrombosis as described earlier. On the follow-up imaging studies, three of seven children who had partial dissolution of PTE had pulmonary hypertension as a sequela (Table I).

\section{DISCUSSION}

The incidences of PTE have varied between 1.7\% and $40 \%$ in selected pediatric patient populations with the diagnosis of nephrotic syndrome, burns, trauma, leukemia, bone marrow transplantation for leukemia, and heart transplantation for dilated cardiomyopathy and congenital heart disease. ${ }^{15-20}$ On the other hand, PTE has been diagnosed in 10\% to $20 \%$ of children with venous thrombosis in pediatric studies. ${ }^{10,21,22}$ The present study was not performed in any selected pediatric population; instead, clinical characteristics, acquired and congenital risk factors, treatment strategies, and long-term outcome in pediatric PTE cases followed in our center were evaluated in this study. Of the total 470 pediatric patients with thrombosis referred to our center, 16 (3.4\%) had PTE and 2 (.4\%) with PTE were lost to follow-up.

PTE commonly occurs in association with DVT. Many PTE cases may be clinically silent or masked by associated symptoms related to underlying diseases. ${ }^{1,23}$ Therefore, all children with documented DVT, moreover any type of thrombosis at any organ, should also be evaluated for PTE. van Ommen et $\mathrm{al}^{10}$ reported 10 patients with PTE, and in their series, five cases (50\%) were associated with DVT. In our series, 8 (50\%) of 16 cases with PTE also had associated thrombosis. These two studies suggest that half of the patients with any type of thrombosis may be associated with PTE.
In children, idiopathic thrombosis occurs rarely, and most of the thrombotic episodes occur in association with underlying malignancy, congenital heart diseases, the presence of CVL and catheters, collagen tissue disorders, renal diseases, burn, dehydration, immobility, obesity, shock, sepsis, surgery, trauma, and vascular malformation. ${ }^{1,2,10}$ In the present study, all children with PTE had at least one laboratory or clinical risk factor that facilitates development of thrombosis. Furthermore, 15 children (93.8\%) had more than one prothrombotic risk factor in this study. Spontaneous PTE is rare, whereas laboratory and/or clinical risk factors for thrombosis increases the risk of PTE development in children.

In our patient group, 6 (37.5\%) were initially diagnosed as having pneumonia for which they received broad-spectrum antibiotic treatment, but clinical improvement was not observed in these patients. Imaging studies performed later led to the accurate diagnosis of PTE. In case numbers 3, 4, 7 , and 11 with PTE and pneumonia, associated thrombosis that may facilitate the development of PTE was also detected. In these cases, associated thrombosis and PTE may produce an image suggestive of pneumonia on chest radiograph. In case number 6 , pneumonia may have resulted from cytomegalovirus infection, and in case number 10, atrial septal defect may have caused the development of pneumonia; pneumonia is a common infection in left-toright shunted congenital heart diseases. The mean age of all patients with PTE was $10.28 \pm 6.83$ years (median: 10.5), whereas the mean age of the patients initially diagnosed with pneumonia was 5.25 \pm 4.29 years (median: 3.5 ), which was younger than that of all patients. The younger patients with PTE may not clearly state the chest pain, which may contribute to the initial misdiagnosis or delay in the accurate diagnosis of PTE. Therefore, especially in young children with pneumonia, PTE should be suspected and imaging studies should be performed when the respiratory symptoms of young children with pneumonia do not improve with antibiotic treatment.

In our series, $6(37.5 \%)$ of 16 patients had congenital heart diseases; five patients $(31.25 \%)$ underwent cardiac surgery, and one patient underwent the Fontan procedure. Children with congenital heart disease can develop thromboembolic complications as a result of altered hemodynamics, prosthetic materials, damaged blood vessels, use of CVLS, and catheterization. PTE is common after right-sided heart bypass surgery, especially the Fontan procedure. ${ }^{1,9}$ Long-term clinical follow-up of patients with congenital heart disease should be per- 
formed with respect to the development of PTE and other thromboembolic complications, especially after cardiac surgery.

Although pediatric malignancy can also lead to the development of PTE, only one child had malignancy in our series. Frequent use of CVLs, coagulation abnormalities resulting from disease or cancer treatment, endothelial damage caused by chemotherapy, use of total parenteral nutrition, and underlying thrombophilia are factors that facilitate thromboembolic complications in malignancy. PTE can be seen in solid tumors and leukemias. ${ }^{1,23}$ It should be kept in mind that acute respiratory distress may be caused by infection, drug reaction, and PTE in a child with malignancy.

In our series, one patient (case 5) with beta thalassemia major who underwent splenectomy first had DVT at the right vena cava inferior, axillary, and subclavian veins, and he received unfractionated heparin treatment. He had cardiotoxicity and hepatotoxicity caused by the high levels of ferritin. Laboratory studies of the patient revealed that he had acquired protein $\mathrm{C}$ deficiency and high levels of fibrinogen and factor VIII levels. Therefore, he had high-risk criteria for recurrence and persistence of venous thrombosis. ${ }^{14}$ In addition, ongoing hemolysis, recurrent infections, and postsplenectomy thrombocytosis in thalassemia major facilitate development of PTE. ${ }^{24}$ After 3 months, he had a second attack of DVT at the same veins and developed PTE, despite receiving LMWH treatment. Supportive therapy for cardiac insufficiency and aggressive anticoagulation therapy (TPA twice, unfractionated heparin for 12 days, and long-term LMWH therapy) were applied, and complete recovery was achieved in this patient.

The patients were also evaluated according to the number of risk factors in each patient: The mean number of risk factors was 3.6 for completely recovered patients and 3.1 for partially recovered patients. Although the number of patients with PTE was limited in the present study, this finding suggests that the type of risk factor in each patient, rather than the number, is an important factor for recovery (Table II). We observed that infection is a more common risk factor in completely recovered patients, whereas noncorrectable underlying disconditions, such as Behçet disease, aneurysm of the pulmonary artery, APA syndrome, Fontan operation, and craniopharyngioma, are among the risk factors in partially recovered patients. In completely recovered patients, three had received TPA and one had undergone thrombectomy for the treatment of PTE, and this may also affect the recovery of the patients
(Table II). Because the numbers of completely and partially recovered patients were limited, no statistical comparison was performed. We suggest that further studies are necessary to confirm our observation obtained from this study.

The D-dimer test is commonly used in the initial clinical evaluation of PTE in adult patients because it has been reported that an elevated D-dimer test result is sensitive in $97.0 \%$ of cases and has a negative predictive value of $99.6 \%$ in adult cases. ${ }^{3}$ However, the role of D-dimer in the diagnosis of pediatric PTE has not been studied in large series. Rajpurkar et $\mathrm{al}^{3}$ reported that 4 (40\%) of 10 children with PTE had a normal D-dimer level in their series; $12(75 \%)$ of 16 children with documented PTE had a high D-dimer level at the time of diagnosis in our patient group. Still, we suggest that D-dimer can be used as a predictive marker for the diagnosis of pediatric PTE.

As is known, hereditary and acquired risk factors are important in the pathogenesis of PTE, as in the development of other thrombosis. Two children with PTE had FV G1691A heterozygous mutation, and one child had MTHFR C677T homozygous mutation in this group of patients. Elevated FVIII level is recognized as one of the high-risk criteria for the persistence or recurrence of venous thrombosis; 8 (50\%) of 16 patients had high FVIII levels in this study. ${ }^{14}$ Another important point in the present study is that 12 patients (75\%) with PTE had three or more risk factors for thrombosis. The patients with three or more risk factors can develop thrombosis easier than those with one to two risk factors. ${ }^{14}$ This study indicates that patients with high-risk criteria can develop PTE easier than those with standard or low-risk criteria. We suggest that thrombotic children with high-risk criteria should be closely followed for development of PTE.

In the diagnosis of PTE, ventilation-perfusion scintigraphy has been the usual initial diagnostic test in both children and adults for more than three decades. The application of the test is easy even in small children. In addition to ventilation-perfusion scintigraphy, helical computed tomography is becoming the preferred diagnostic imaging technique for pediatric PTE in many centers. It can visualize the emboli and be performed quickly even in critically ill children. ${ }^{3,25,26}$ In our center, both imaging techniques have been used in the diagnosis of PTE.

\section{CONCLUSIONS}

When a child with thrombosis at any site of the body develops unexpected respiratory symptoms or 
pneumonia resistant to antibiotic treatment, imaging studies should be performed for diagnosis of PTE. Prompt diagnosis, early administration of anticoagulation therapy, and supportive therapy may rescue the life of children with PTE, and complete recovery can be achieved in these children. Furthermore, patients with high-risk criteria, including three or more risk factors, should be followed closely for the development of PTE and treated with effective anticoagulant therapy for complete recovery.

\section{REFERENCES}

1. Babyn PS, Gahunia HK, Massicotte P. Pulmonary thromboembolism in children. Pediatr Radiol 2005;35:258-74

2. Andrew M, David M, Adams M, et al. Venous thromboembolic complications (VTE) in children: first analyses of the Canadian Registry of VTE. Blood 1994;83:1251-7.

3. Rajpurkar M, Warrier I, Chitlur M, et al. Pulmonary embolismexperience at a single children's hospital. Thromb Res 2002; 113:633-703

4. Olivier C, Blondiaux E, Blanc T, Borg JY, Dacher JN. Catastrophic antiphospholipid syndrome and pulmonary embolism in a 3-year-old child. Pediatr Radiol 2006;36:870-3.

5. Sridhar AV, Rao NK, Chakraborty S. A six-year-old with fatal pulmonary embolism. Acta Paediatr 2005;94:977-9.

6. Rai Mittal B, Singh S, Bhattacharya A, Prasad V, Singh B. Lung scintigraphy in the diagnosis and follow-up of pulmonary thromboembolism in children with nephrotic syndrome. Clin Imaging 2005;29:313-6.

7. Athanassiadou F, Kourti M, Tragiannidis A, et al. Pulmonary embolism due to invasive aspergillosis in a child with acute myelogenous leukemia. Pediatr Blood Cancer 2005;45: 1001-2.

8. Byard RW, Cutz E. Sudden and unexpected death in infancy and childhood due to pulmonary thromboembolism. An autopsy study. Arch Pathol Lab Med 1990;114:142-4

9. Buck JR, Connors RH, Coon WW, Weintraub WH, Wesley JR, Coran AG. Pulmonary embolism in children. J Pediatr Surg $1981 ; 16: 385-91$.

10. van Ommen $\mathrm{CH}$, Heijboer $\mathrm{H}$, Buller HR, Hirasing RA, Heijmans HS, Peters M. Venous thromboembolism in childhood: a prospective two-year registry in The Netherlands. J Pediatr $2001 ; 139: 676-81$
11. Bertina RM, Koeleman BP, Koster T, et al. Mutation in blood coagulation factor $\mathrm{V}$ associated with resistance to activated protein C. Nature 1994;369:64-7.

12. Poort SR, Rosendaal FR, Reitsma PH, Bertina RM. A common genetic variation in the 3'-untranslated region of the pro thrombin gene is associated with elevated plasma prothrombin levels and an increase in venous thrombosis. Blood 1996;88:3698-703

13. Goyette P, Sumner JS, Milos R, et al. Human methylenetetrahydrofolate reductase: isolation of cDNA, mapping and mutation identification. Nat Genet 1994;7:195-200

14. Manco-Johnson MJ. How I treat venous thrombosis in chil dren. Blood 2006; 107:21-9

15. Hoyer PF, Gonda S, Barthels M, Krohn HP, Brodehl J. Thromboembolic complications in children with nephrotic syndrome. Risk and incidence. Acta Paediatr Scand 1986;75: 804-10.

16. Desai MH, Linares HA, Herndon DN. Pulmonary embolism in burned children. Burns 1989;15:376-80.

17. Hsu DT, Addonizio LJ, Hordof AJ, Gersony WM. Acute pulmonary embolism in pediatric patients awaiting heart transplantation. J Am Coll Cardiol 1991;17:1621-5

18. Marraro G, Uderzo C, Marchi P, Castagnini G, Vaj PL, Masera G. Acute respiratory failure and pulmonary thrombosis in leukemic children. Cancer 1991;67:696-702.

19. Uderzo C, Marraro G, Riva A, et al. Pulmonary thromboem bolism in leukaemic children undergoing bone marrow transplantation. Bone Marrow Transplant 1993;11:201-3

20. McBride WJ, Gadowski GR, Keller MS, Vane DW. Pulmonary embolism in pediatric trauma patients. J Trauma 1994;37 913-5.

21. Nuss R, Hays T, Manco-Johnson M. Childhood thrombosis Pediatrics 1995;96:291-4

22. Monagle P, Adams M, Mahoney M, et al. Outcome of pediatric thromboembolic disease: a report from the Canadian Childhood Thrombophilia Registry. Pediatr Res 2000;47: 763-6.

23. van Ommen $\mathrm{CH}$, Peters $\mathrm{M}$. Acute pulmonary embolism in childhood. Thromb Res 2006;118:13-25

24. Michaeli J, Mittelman M, Grisaru D, Rachmilewitz EA. Thromboembolic complications in beta thalassemia major. Acta Haematol 1992;87:71-4

25. Gurgey A, Aslan D. Outcome of noncatheter-related thrombosis in children: influence of underlying or coexisting factors. J Pediatr Hematol Oncol 2001;23:159-64

26. Schoepf UJ, Goldhaber SZ, Costello P. Spiral computed tomography for acute pulmonary embolism. Circulation 2004 109:2160-7. 